\title{
Prolonged Type 1 Metabotropic Glutamate Receptor Dependent Synaptic Signaling Contributes to Spino-Cerebellar Ataxia Type 1
}

\author{
Emmet M. Power, Adrienne Morales, and Ruth M. Empson \\ Department of Physiology, Brain Health Research Centre, Brain Research New Zealand, Otago School of Medical Sciences, University of Otago, Dunedin, \\ New Zealand 9016
}

\begin{abstract}
Type 1 metabotropic glutamate receptor (mGluR1)-dependent signaling at parallel fiber to Purkinje neuron synapses is critical for cerebellar function. In a mouse model of human spino-cerebellar ataxia type 1 (early SCA1, 12 weeks) we find prolonged parallel fiber mGluR1-dependent synaptic currents and calcium signaling. Acute treatment with a low dose of the potent and specific activitydependent mGluR1-negative allosteric modulator JNJ16259685 shortened the prolonged mGluR1 currents and rescued the moderate ataxia. Our results provide exciting new momentum for developing mGluR1-based pharmacology to treat ataxia.
\end{abstract}

Key words: ataxia; calcium; cerebellum; mGluR1; parallel fibers

\section{Significance Statement}

Ataxia is a progressive and devastating degenerative movement disorder commonly associated with loss of cerebellar function and with no known cure. In the early stages of a mouse model of human spinocerebellar ataxia type 1, SCA1, where mice exhibit only moderate motor impairment, we detect excess "gain of function" of metabotropic glutamate receptor signaling at an important cerebellar synapse. Because careful control of this type of signaling is critical for cerebellar function in mice and humans, we sought to remove the excess signaling with a powerful, readily available pharmacological modulator. Remarkably, this pharmacological treatment acutely restored normal motor function in the ataxic mice. Our results pave the way for exploring a new avenue for early treatment of human ataxias.

\section{Introduction}

Normal function of cerebellar Purkinje neurons (PNs) depends on type 1 metabotropic glutamate receptors (mGluR1) that drive phosphoinositide-mediated signaling events at parallel fiber (PF) synapses (Batchelor and Garthwaite, 1997). Dysfunction of this receptor and its downstream signaling effectors such as $\mathrm{Ca}^{2+}$ mobilization, protein kinase $\mathrm{C}$ and the transient receptor potential current, TRPC3, are all implicated in the pathophysiology of cerebellar ataxias (Becker et al., 2009; Kasumu et al., 2012; Kato et al., 2012). A central role for PN mGluR1 is best illustrated by the ataxic phenotype of knock-out mice that can be reversed by $\mathrm{PN}$ -

\footnotetext{
Received Nov. 2, 2015; revised March 26, 2016; accepted April 2, 2016.

Author contributions: E.M.P. and R.M.E. designed research; E.M.P., A.M., and R.M.E. performed research; E.M.P., A.M., and R.M.E. analyzed data; E.M.P. and R.M.E. wrote the paper.

This work was supported by a University of Otago PhD scholarship to E.M.P., and an OSMS Dean's Bequest Grant and Otago Medical Research Foundation summer scholarship to A.M.

The authors declare no competing financial interests.

Correspondence should be addressed to Ruth Empson, University of Otago, Dunedin, New Zealand 9016. E-mail: ruth.empson@otago.ac.nz.

DOI:10.1523/JNEUROSCI.3953-15.2016

Copyright (C) 2016 the authors $\quad 0270-6474 / 16 / 364910-07 \$ 15.00 / 0$
}

specific re-expression of mGluR1 (Ohtani et al., 2014). Human ataxic patients also express mGluR1 autoantibodies (Sillevis Smitt et al., 2000), and mutations to mGluR1 and TRPC3 occur in two rare, early onset autosomal-recessive ataxias (Guergueltcheva et al., 2012; Fogel et al., 2015).

mGluR1s may therefore provide a promising target for pharmacological treatment of cerebellar ataxias, especially as advances in medicinal chemistry now provide powerful and specific activity-dependent positive allosteric modulators (PAMs) and negative allosteric modulators (NAMs) for mGluR1 (Wu et al., 2014). In several mouse models of autosomal-dominant human spinocerebellar ataxias (SCAs) CAG trinucleotide (Q) expansion disrupts nuclear transcription programs. In SCA1, loss of ROR- $\alpha$ mediated (Serra et al., 2006) signaling drives reduced expression of mGluR1, TRPC3, and the PN-specific excitatory amino acid transporter EAAT4 (Serra et al., 2004). mGluR1 expression and function are also reduced in mouse models of SCA5 and SCA3 (Armbrust et al., 2014; Konno et al., 2014) and the mGluR1 PAM improves motor function in severe SCA1 (Notartomaso et al., 2013). Conversely, in SCA28 mice, mGluR1 activity might instead be pathologically elevated, because reducing mGluR1 expression reduces $\mathrm{Ca}^{2+}$ rises and 
alleviates the ataxia (Maltecca et al., 2015). Further, TRPC3 currents are enhanced in SCA14 and ataxic moonwalker and hotfoot-4J mice, consistent with excessive mGluR1 activity (Hartmann et al., 2008; Becker et al., 2009; Shuvaev et al., 2011; Kato et al., 2012). Therefore, mGluR1 PAMs and NAMs may both have potential for treating a variety of cerebellar ataxias.

Here, we show that moderate SCA1 ataxia involves prolonged mGluR1 synaptic signaling at cerebellar PF synapses, and is reversed by an mGluR1 NAM. These findings provide exciting new momentum for mGluR1-based treatment of ataxias.

\section{Materials and Methods}

Mice. The University of Otago Animal Ethics Committee approved all procedures. We used 12-week-old male and female SCA1 82Q Tre/Tre; tTA/tTA, called $82 Q$ mice, and wild-type FVB/pcp2 tTA/tTA, called WT mice kindly provided by H. T. Orr (University of Minnesota, USA) (Zu et al., 2004).

Motor behavior. We tested groups of male and female mice separately, at the same time each day in a purpose-built room with sodium lighting. Chronic motor performance was assessed with an accelerating rotarod (latency to fall; Rotamex, Columbus Instruments $4-40$ rpm over 5 min, 10 min between trials, 4 trials/d for $4 \mathrm{~d}$; Clark et al., 1997). Acute motor performance was assessed with a fixed speed rotarod (latency to fall; 8 rpm for $2 \mathrm{~min}$, minimum 2 min between trials). We measured hindpaw base-of-support (Catwalk, Noldus) from 3 to 5 runway crossings per mouse. Thirty minutes before acute testing, mice received subcutaneous injections of JNJ16259685 (0.03 mg/kg, <0.3 ml; Tocris Bioscience) in sterile saline with $10 \%$ hydroxypropyl-betacyclodextrin (ThermoFisher) as vehicle, or vehicle alone. Mice were not pretrained, poor performers (latency $<10 \mathrm{~s}$ ) were immediately re-trialed and persistent poor performers excluded.

Electrophysiology and calcium imaging. Mice were rapidly euthanized with $\mathrm{CO}_{2}$ and cerebellar slices $(300 \mu \mathrm{m})$ prepared using the following (in mM): 75 sucrose, $87 \mathrm{NaCl}, 2.5 \mathrm{KCl}, 1.25 \mathrm{NaH}_{2} \mathrm{PO}_{4}, 6 \mathrm{MgCl}_{2}, 0.5 \mathrm{CaCl}_{2}, 25$ $\mathrm{NaHCO}_{3}$, and 25 glucose (Sigma-Aldrich) and maintained in artificial CSF (aCSF) containing the following (in mM): $126 \mathrm{NaCl}, 3 \mathrm{KCl}, 1 \mathrm{NaH}_{2} \mathrm{PO}_{4}, 26$ $\mathrm{NaHCO}_{3}, 2.4 \mathrm{CaCl}_{2}, \mathrm{MgCl}_{2}$, and 10 glucose before perfusion $(2.5 \mathrm{ml} / \mathrm{min})$ with aCSF containing $50 \mu \mathrm{M}$ picrotoxin, $25 \mu \mathrm{M}$ CNQX (1,2,3,4-tetrahydro6-nitro-2,3-dioxo-benzo[f] quinoxaline-7-sulfonamide) followed by $10 \mathrm{~min}$ $50 \mu \mathrm{M}$ TBOA (DL-threo- $\beta$-benzyloxyaspartic acid) or $200 \mu \mathrm{M}$ (S)MCPG ((S)- $\alpha$-methyl-4-carboxyphenylglycine) or $10 \mathrm{~min} 5 \mathrm{nM}$, then $20 \mathrm{nM}$ JNJ16259685 (Tocris Bioscience).

Whole-cell voltage-clamp recordings from PNs from folia III to $\mathrm{V}$ $(-70 \mathrm{mV})$ used electrodes containing the following (in $\mathrm{mM}$ ): $4.5 \mathrm{KCl}, 20$ $\mathrm{KOH}, 3.48 \mathrm{MgCl}_{2}, 4 \mathrm{NaCl}, 120 \mathrm{~K}$ gluconate, 10 HEPES, 8 sucrose, 10 EGTA, $4 \mathrm{Na}_{2} \mathrm{ATP}$, and $0.4 \mathrm{Na}_{2} \mathrm{GTP}, 8$ biocytin (Sigma-Aldrich); osmolarity 295-305 mOsm, pH 7.3, resistance 3-5 M 2 . For $\mathrm{Ca}^{2+}$ imaging, HEPES and $100 \mu \mathrm{M}$ Oregon Green BAPTA-1 (OGB-1, Life Technologies) replaced EGTA. Cell-attached recordings in picrotoxin used electrodes containing aCSF. Recordings used an Axopatch 200B (whole-cell) or Multiclamp (cell-attached) (Molecular Devices) digitized at $10 \mathrm{kHz}$ (Digidata 1440A, Molecular Devices; or 1401plus CED) and analyzed with pClamp 10 (Molecular Devices). We excluded recordings with holding current $<-200 \mathrm{pA}$ or series resistance $>35 \mathrm{M} \Omega$ with $>10 \%$ change throughout the experiment. PF stimulation (DS2A Digitimer, $200 \mu$ s duration, $10-30 \mathrm{~V}, 0.03 \mathrm{~Hz}$ interval) evoked a $400-600 \mathrm{pA}$ peak EPSC at $10 \times$ stimulation $\left(200 \mathrm{~Hz} ; 3-5\right.$ sweep average). During $\mathrm{Ca}^{2+}$ imaging, we depolarized voltage-clamped PNs to $0 \mathrm{mV}$ for $400 \mathrm{~ms}$ to measure synapse-independent $\mathrm{Ca}^{2+}$ responses and to fill $\mathrm{Ca}^{2+}$ stores.

Wide-field fluorescence-based $\mathrm{Ca}^{2+}$ imaging $(100 \mathrm{~Hz}, 4 \times$ binned; Hamamatsu C9100) commenced 20 min after establishing whole-cell configuration. PF stimulation evoked a local rise in fluorescence corrected for bleaching (no stimulation) normalized to baseline fluorescence, $F(\Delta \mathrm{F} / \mathrm{F})$ average of 5, using Simple PCI and Excel.

Immunohistochemistry. Slices containing biocytin-filled PNs were fixed in cold $4 \%$ paraformaldehyde in PBS ( $75 \mathrm{~mm} \mathrm{Na}_{2} \mathrm{HPO}_{4}$ and $25 \mathrm{~mm}$ $\mathrm{NaH}_{2} \mathrm{PO}_{4}$ ), $2.7 \mathrm{~mm} \mathrm{KCl}, 137 \mathrm{~mm} \mathrm{NaCl}, \mathrm{pH} 7.4$ (all Sigma-Aldrich). After $\mathrm{PBS}$ washes and permeabilization (PBS $+0.3 \%$ Triton $\mathrm{X}-100)$ slices were incubated with Streptavidin AlexaFluor 647 (Life Technologies; $2 \mu \mathrm{g} / \mathrm{ml}$, $4 \mathrm{~h}$, room temperature) before reconstruction (Nikon A1R confocal; $0.21 \mu \mathrm{m} /$ pixel $x, y, 1 \mu \mathrm{m} z$-step; $638 \mathrm{~nm}$ laser excitation, Coherent Scientific; $630 \pm 50 \mathrm{~nm}$ emission). Immunohistochemistry used anticalbindin, to measure molecular layer (ML) height, and anti-vGlut2 to measure climbing fiber (CF) extension (guinea-pig, 214005; rabbit, 135405 respectively, both Synaptic Systems; 1:1000 overnight, room temperature) with secondary detection (AlexaFluor 647 and 555conjugated antibodies, respectively; $1: 500,4 \mathrm{~h}$, room temperature; Life Technologies) before confocal imaging $(0.4 \mu \mathrm{m} /$ pixel $x, y, 543$ and 638 $\mathrm{nm}$ laser excitation $525 \pm 50,630 \pm 50 \mathrm{~nm}$ emission, respectively). We did not detect labeling in the absence of primary antibody.

Analysis and statistics. We measured mGluR1 current duration from 3 to 5 sweeps and spike firing frequency from a 3 min recording. $\Delta \mathrm{F} / \mathrm{F}$ recovery kinetics used a single exponential fit and integrated the area under the curve to quantify PF-evoked long-lasting $\mathrm{Ca}^{2+}$ signals (GraphPad, Prism). We obtained average ML height and CF extension from five regions in folia III-V across two to three slices per mouse using ImageJ. Sholl analysis (http://fiji.sc/Sholl_Analysis; Ferreira et al., 2014) used a separation radius of $10 \mu \mathrm{m}$.

Statistical analysis used two-way repeated-measures ANOVA with Bonferroni's multiple comparisons and Students unpaired $t$ tests where appropriate (GraphPad Prism).

\section{Results}

We confirmed behavioral and neuronal deficits in 12-week-old mice with $\mathrm{PN}$-specific $82 \mathrm{Q}$ repeats in the ataxin-1 gene $(82 \mathrm{Q}$ mice) as a model of moderate SCA1. $82 Q$ mice exhibited reduced motor performance (Fig. 1 A, B; Clark et al., 1997; Zu et al., 2004) and reduced complexity of $\mathrm{PN}$ outer dendrites, a reduced $\mathrm{PN}$ height with CF retraction (Fig. 1C-G; Barnes et al., 2011) and reduced PN firing (Fig. $1 \mathrm{H}, \mathrm{I}$; Hourez et al., 2011).

We next sought to assess the physiological contribution of mGluR1 to PF-PN synaptic signaling in moderately ataxic $82 \mathrm{Q}$ PNs. We recorded PF-evoked mGluR1-dependent slow EPSCs in PNs, with and without the excitatory amino acid transporter (EAAT) blocker TBOA. Slow EPSCs were significantly prolonged in $82 Q$ compared with WT PNs but of similar amplitude (Fig. $2 A$, dark traces, $B, C$ dark bars). These slow currents were largely abolished by $200 \mu \mathrm{M}$ (S)MCPG and 20 nM JNJ16259685 confirming their mGluRlorigin (both $n=3$ ) and previous work shows that these currents are mediated by TRPC 3 activation (Hartmann et al., 2008). The longer currents in $82 Q \mathrm{PNs}$ occurred at all stimulation intensities so were not a consequence of altered PF recruitment (Fig. 2D). To test whether reduced expression of EAAT4 was responsible for the prolonged mGluR1 currents we eliminated EAATs with TBOA (Fig. $2 A$, light traces). TBOA increased the amplitude and duration of PF-evoked mGluR1 currents in $W T$ but not $82 Q \mathrm{PNs}$ (Fig. 2A-C) consistent with a loss of EAAT4 in $82 Q$ PNs.

PF-evoked mGluR1 signaling elevates $\mathrm{Ca}^{2+}$ in PN dendrites (Canepari and Ogden, 2006), so we tested whether the longer PFevoked mGluR1 current also prolonged PF-evoked dendritic $\mathrm{Ca}^{2+}$ responses. 82Q PNs exhibited modestly prolonged $\mathrm{Ca}^{2+}$ signals in their outer dendrites compared with WT (Fig. 2E,F, filled bars). Although subtle, these enhanced long-lasting $\mathrm{Ca}^{2+}$ signals were synapse-specific, because depolarization-evoked $\mathrm{Ca}^{2+}$ responses were unchanged between $W T$ and $82 Q$ (Fig. 2G, filled bars). Similarly, the fast component of the PF-evoked $\mathrm{Ca}^{2+}$ signals were similar in $W T$ and $82 Q \mathrm{PN}$ dendrites (Fig. 2G, open bars) confirming a specific increase of long-lasting $\mathrm{Ca}^{2+}$ signals in $82 \mathrm{Q} \mathrm{PNs}$. In all cases the long-lasting $\mathrm{Ca}^{2+}$ signals were reduced by the mGluR1 antagonist (S)MCPG (Fig. 2F, lighter bars). Removal of the mGluR1 component revealed $\mathrm{PF}$-evoked dendritic $\mathrm{Ca}^{2+}$ signals that took longer to recover in $82 \mathrm{Q}$ compared with WT PNs (Fig. $2 \mathrm{H}$ ). 
To address the relevance of prolonged cerebellar PF-evoked mGluR1 signaling for the ataxic phenotype, we treated mice with JNJ16259685 (JNJ), a potent and specific mGluR1 NAM. JNJ binds deep in the receptor complex only after glutamate binding (Wu et al., 2014) and behaves as an activity-dependent NAM. We administered $0.03 \mathrm{mg} / \mathrm{kg}$ JNJ to reduce cerebellar mGluR1 occupancy by $\sim 20-30 \%$ in vivo (Lavreysen et al., 2004) predicting a greater effect on motor behavior in $82 Q$ mice where mGluR1 signaling is increased. As seen in Figure 3, $A$ and $B$, JNJ restored motor performance in $82 Q$ mice without influencing WT mice. To help explain these findings we simulated the in vivo treatment by applying $5 \mathrm{~nm}$ JNJ to cerebellar slices that reduced mGluR1 current duration in $82 Q$ but not WT PNs, and to WT levels (Fig. 3C-E). Importantly, $20 \mathrm{~nm}$ JNJ reduced mGluR1 currents (by $\sim 90 \%$ ) in both $W T$ and $82 Q$ cells $(n=3)$ consistent with its actions in normal cerebellar slices (Fukunaga et al., 2007). Together our findings provide a compelling mechanistic link between removal of overactive mGluR1-mediated synaptic signaling by JNJ in $82 \mathrm{Q}$ PNs and temporary relief from moderate ataxia in $82 Q$ mice.

\section{Discussion}

We found prolonged mGluR1 activity at cerebellar PF-PN synapses from moderately ataxic SCA1 mice. Removing this excessive activity with an mGluR1 NAM improved motor performance in these mice and may provide a promising approach to treat cerebellar ataxia.

\section{Q model of SCA1}

The PN-specific $82 Q$ mouse model of SCA1 used here recapitulates many aspects of human SCA1. The mice performed poorly on the accelerating rotarod and exhibited an increased hindpaw stance consistent with moderate ataxia (Fig. 1), as in the B05 SCA1 mouse (Clark et al., 1997). 82Q expression resulted in shrunken PNs with decreased complexity in outer dendrites and CF retraction (Barnes et al., 2011). 82Q PN simple spike firing was also slower (Fig. 1), as seen earlier (Hourez et al., 2011) and later (Dell'Orco et al., 2015) in SCA1.

\section{Prolonged mGluR1-mediated PF synaptic signaling in SCA1}

We observed functionally prolonged PFevoked mGluR1-mediated inward currents in PNs from ataxic mice (Fig. $2 A-C$ ), that were consistent with mGluR1-dep-
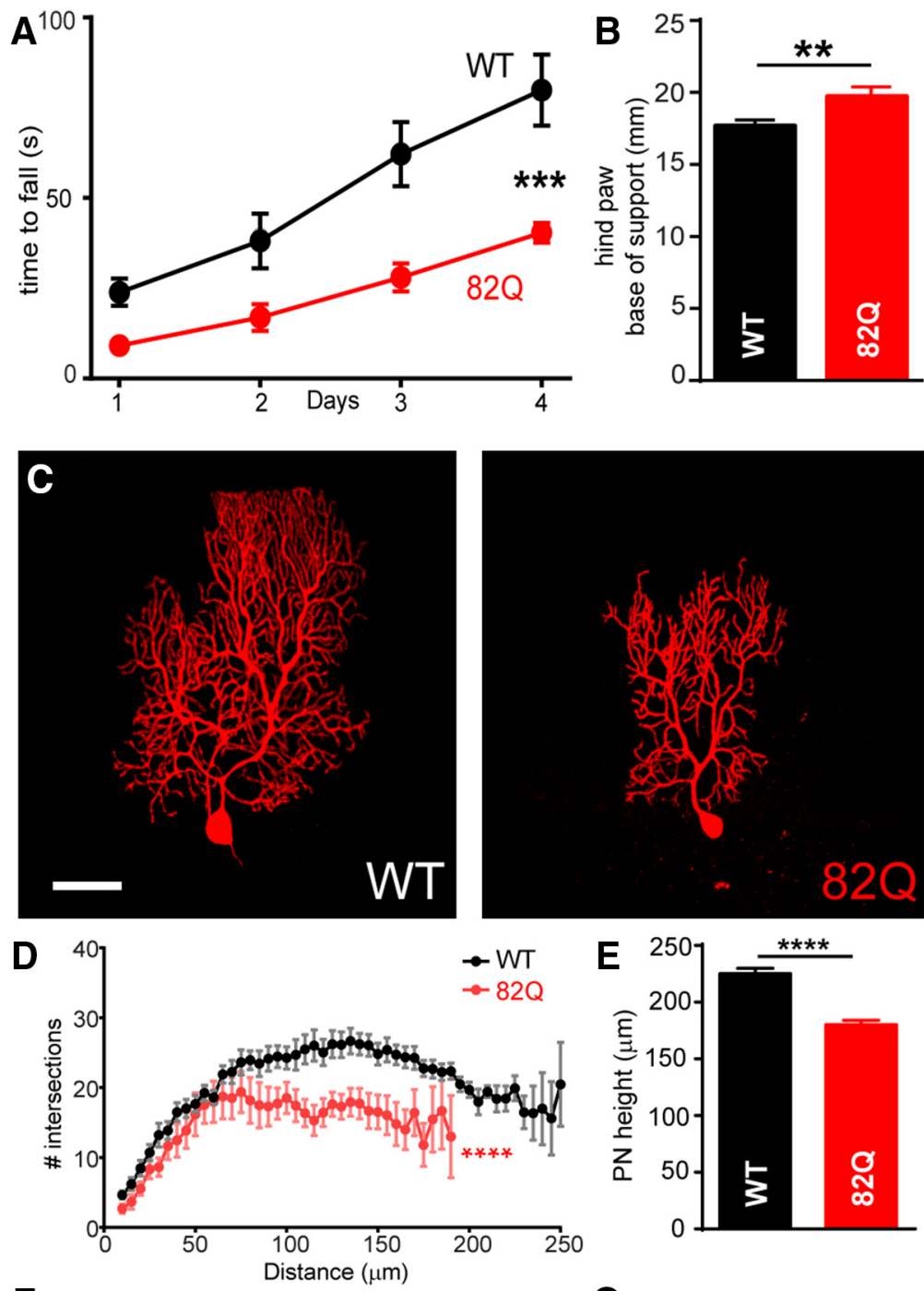
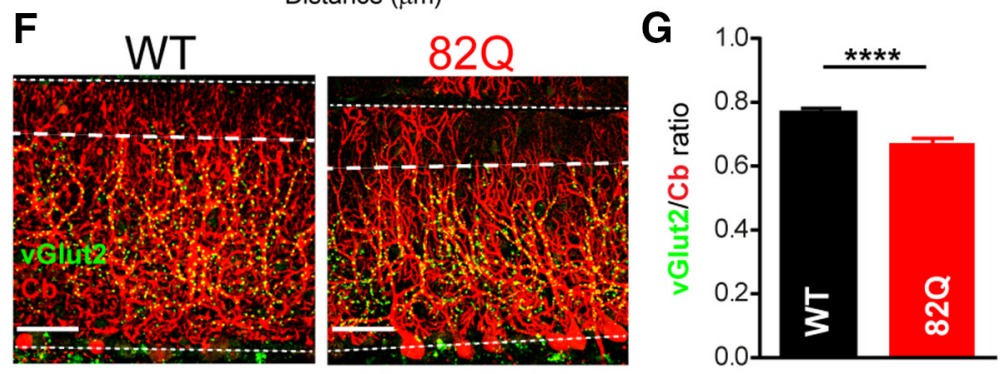

H
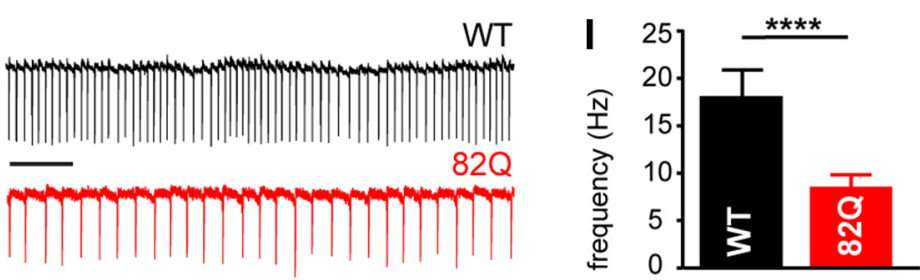

Figure 1. Moderate ataxia and cellular changes in 12-week-old $82 Q$ mice. $\boldsymbol{A}$, Reduced performance on the accelerating rotarod ${ }^{* * *} F_{(1,19)}=15.41, p=0.005, n=10$ /group, two-way ANOVA) and $(\boldsymbol{B})$ increased hindpaw base-of-support (with paw prints). ${ }^{* *} p=0.008, t$ test in 820 compared with WT mice. Data are mean \pm SEM. C, Representative reconstructed PNs, with Sholl plots in $\boldsymbol{D}$ showing a reduced number of intersections in $82 Q \mathrm{PN}$ dendrites $\left({ }^{* * * *} F_{(1,21)}=62.4, p<\right.$ $0.0001, n=8$ /group, two-way ANOVA) and $\boldsymbol{E}$ shows their reduced height. ${ }^{* * * *} p<0.0001 t$ test. $\boldsymbol{F}, \boldsymbol{G}$, Reduced vGlut2positive CF extension in the thinner calbindin-positive (Cb) ML of $82 Q$ mice. ${ }^{* * * *} p<0.0001(n=11) t$ test. $\boldsymbol{H}, \boldsymbol{I}$, Reduced simple spike firing in $82 Q$ PNs. Scale bar, 500 ms. ${ }^{* * *} p<0.0001,(n=8) t$ test. Scale bars: $\boldsymbol{A}, \boldsymbol{C}, 50 \mu \mathrm{m}$. Data are mean \pm SEM. 
A

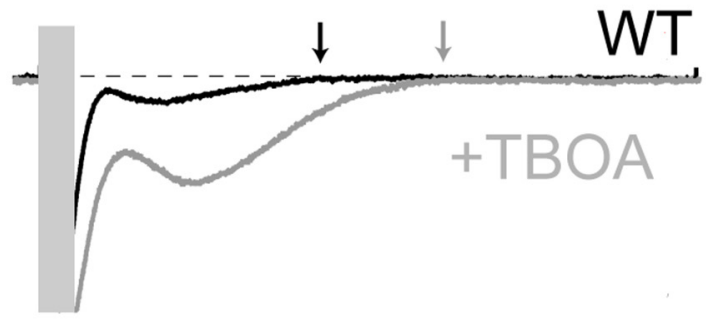

C

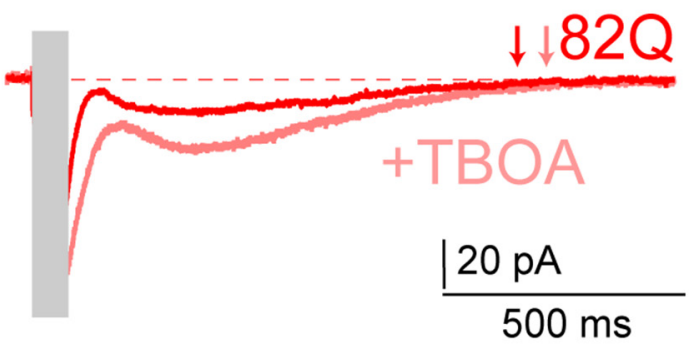

B

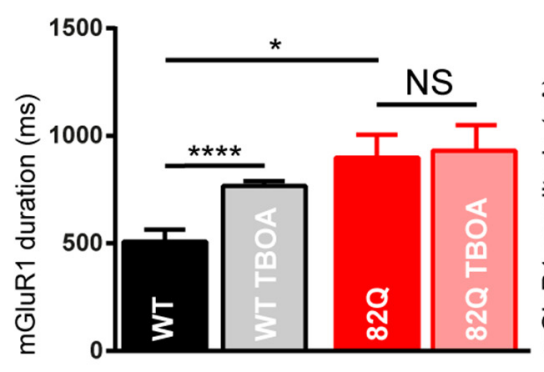

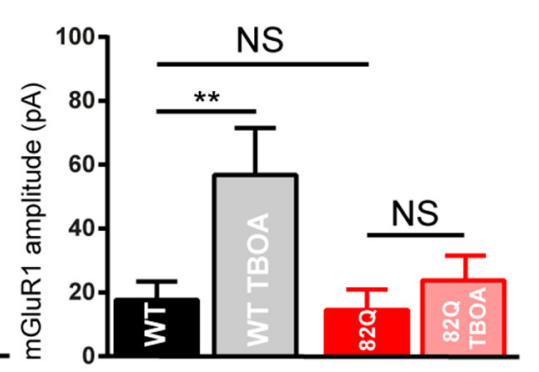

D

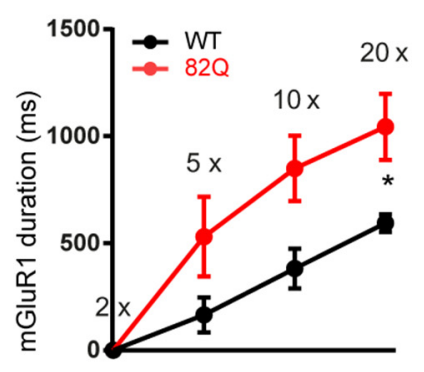

E
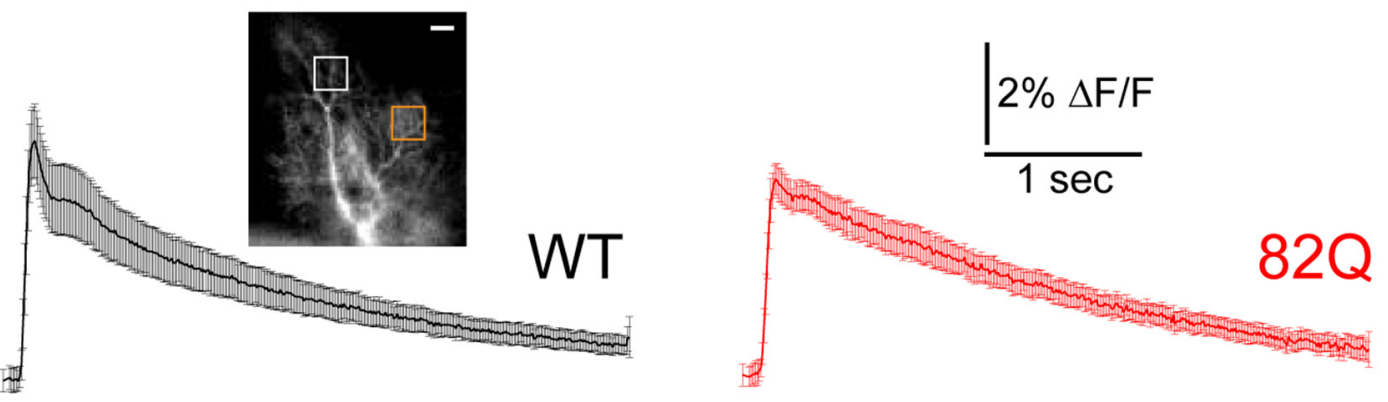

F

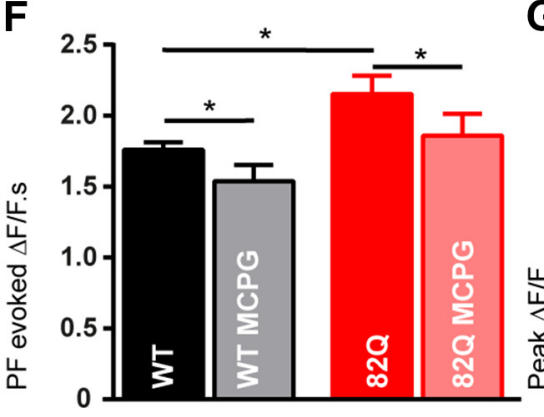

G
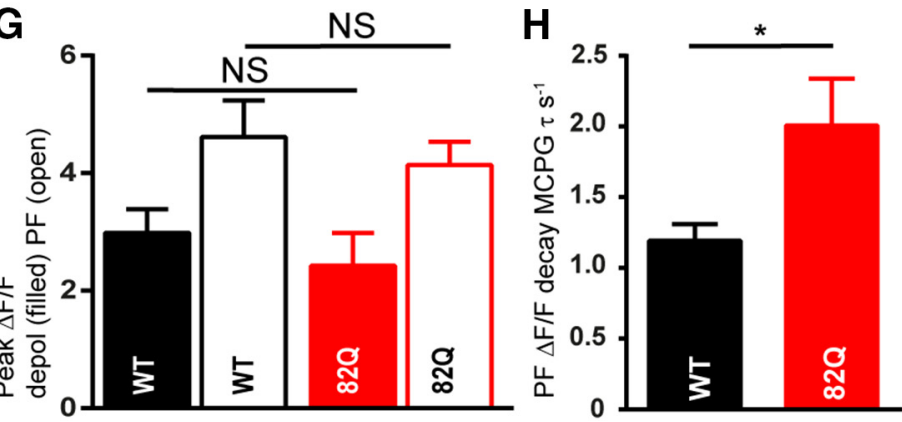

Figure 2. Prolonged mGluR1 synaptic signaling in $82 Q$ mice. A, Prolonged PF-evoked mGluR1-mediated synaptic currents $(10 \times$ stimulation, $200 \mathrm{~Hz}$, stimulus artifacts obscured with gray boxes) in PNs from WT and $82 Q$ mice in the presence and absence of TBOA to block glutamate transporters. $B$, Longer duration mGluR1 current in $82 Q \mathrm{PNs}$ versus $W T:{ }^{*} F_{(1,9)}=8.03$, $p=0.02, n=5$ each, two-way ANOVA and increased by TBOA in WT PNs but not $82 Q$ PNs; ${ }^{* * * *} p<0.0001$ two-way ANOVA, multiple comparison. C, mGluR1 current peak amplitude is similar between WT and $82 Q$ PNs: $F_{(1,9)}=2.24, p=0.17$, two-way ANOVA and increased by TBOA in WT but less so in $82 Q$; ** $p<0.01$ two-way ANOVA. D, Longer mGluR1 currents with increasing stimulation $(2 \times-20 \times)$ in 820 versus WTPNs: ${ }^{*} F_{(1,44)}=21.6, p<0.0001, n=9$, two-way ANOVA; NS, not significant. E, Mean (and SEM) of Ca ${ }^{2+}$ signals in PN outer dendrites from WT and 820 mice following $10 \times$ PF stimulation ( $200 \mathrm{~Hz}$ ). Inset, An 0GB-1 filled PN dendrite (scale bar, $20 \mu \mathrm{m}$ ) with locally responsive dendrite (white box) used to extract fluorescence changes and remote unresponsive area (orange box). $\boldsymbol{F}$, The increased mean integrated slow PF-mediated $\mathrm{Ca}^{2+}$ signal in $820 \mathrm{PNs}:{ }^{*} F_{(1,10)}=8.13, p=0.017, n=6$ each, two-way ANOVA; (S)MCPG reduced the $\mathrm{Ca}^{2+}$ signal in both WT and $82 Q \mathrm{PN}$ dendrites: $F_{(1,10)}=6.3, p=0.013$, to similar values; $p=0.12, t$ test. $F$, Peak $C a^{2+}$ rises were similar across all PNs; $p=0.4, t$ test $(n=6)$; NS, nonsignificant. $G$, In the presence of (S)MCPG, the mean PF-evoked $\mathrm{Ca}^{2+}$ decay time constant, $\tau$, is longer in $82 \mathrm{PNN}$ dendrites; ${ }^{*} p=0.018, t$ test $(n=6)$. Error bars are mean \pm SEM.

endent TRPC3 activation. These currents are also enhanced in spontaneously ataxic moonwalker and hotfoot-4J mice and in SCA14 mice (Becker et al., 2009; Shuvaev et al., 2011; Kato et al., 2012), suggesting that enhanced mGluR1synaptic signaling may be a common feature of several ataxias. Interestingly, mGluR1/ TRPC3-positive PNs exhibit particularly high-frequency simple spikes (Zhou et al., 2014) so altering their signaling could be especially disruptive.
The prolonged mGluR1 current in $82 \mathrm{Q}$ PNs seen here contrasts with reduced mGluR1 (and TRPC3) expression in midand late-stage SCA1 (Zu et al., 2004; Notartomaso et al., 2013). Instead, we show that the functionally prolonged mGluR1 current is explained by a loss of glutamate transporter activity (Fig. $2 B, C$ ), most likely the high affinity, low capacity PN-specific EAAT4 that declines early in SCA1 (Serra et al., 2004). EAAT4 is also disrupted in the $\beta$-III spectrin knock-out SCA5 mouse and 

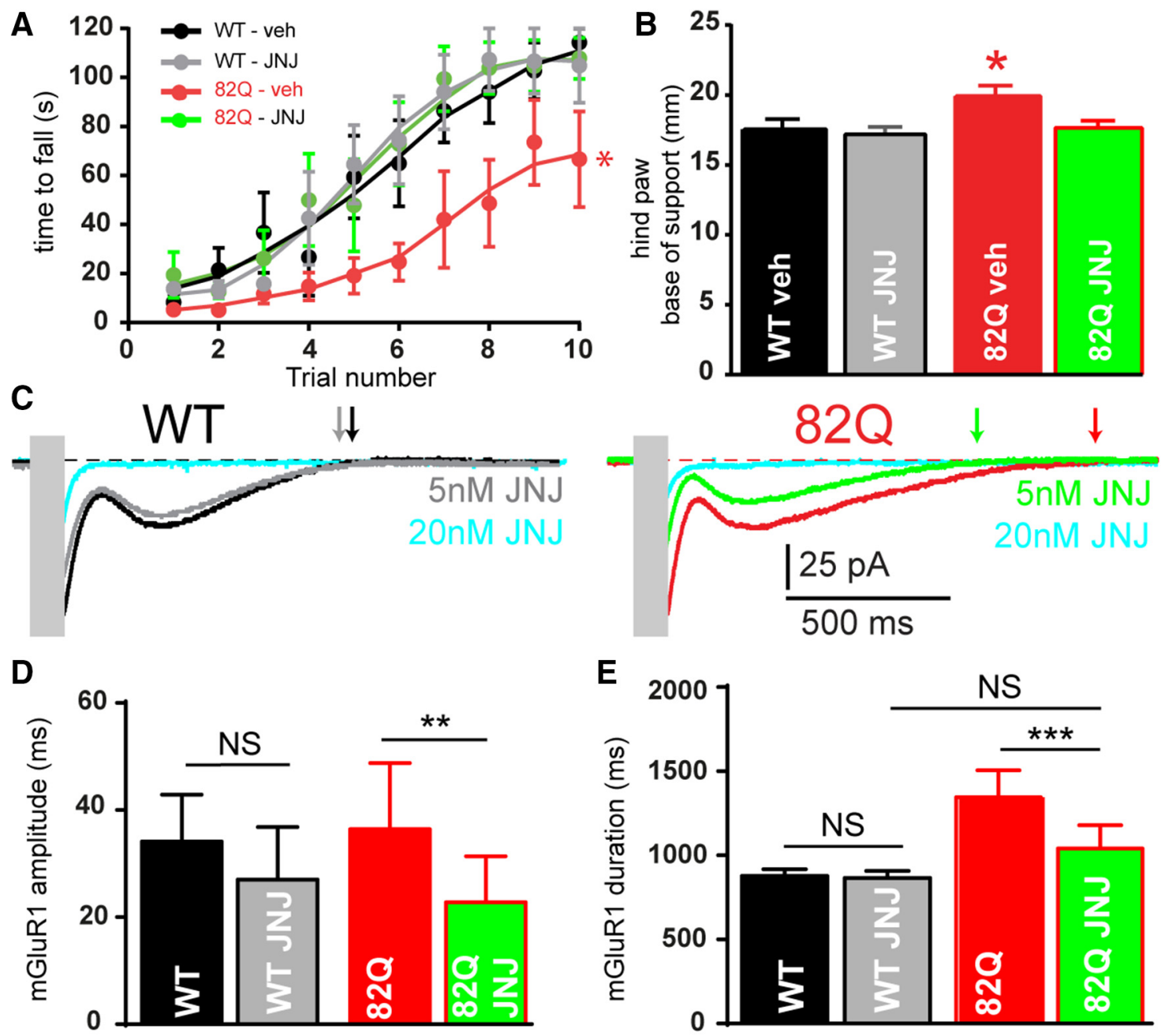

Figure 3. The mGluR1 NAM, JNJ16259685 improves acute motor performance of 820 mice. JNJ16259685 $(0.03 \mathrm{mg} / \mathrm{kg})$ restores $(A)$ rotarod performance: ${ }^{*} F_{(3,25)}=3.3, p=0.03$, two-way ANOVA; and $(\boldsymbol{B})$ hindpaw base-of-support: ${ }^{*} F_{(3,25)}=3.8, p=0.02$, two-way ANOVA, in $82 Q$ but not WT mice, $n=7-8 /$ group. C, JNJ16259685 (5 nm) reduces the amplitude (D) and duration $(\boldsymbol{E})$ of $82 Q$ but not WT mGluR1 currents: ${ }^{* *} F_{(1,9)}=19.9, p<0.005 ;{ }^{* * *} F_{(1,9)}=27, p<0.001, n=5$ each group, two-way ANOVA. Symbols and error bars represent mean \pm SEM.

in human SCA5 (Ikeda et al., 2006; Perkins et al., 2010). Perhaps, as the influence of EAAT4 declines in SCA1, reduced mGluR1 expression is necessary to control excessive mGluR1 signaling.

The longer mGluR1 currents in SCA1 may also arise in response to $82 \mathrm{Q}$ toxicity when $\mathrm{PKC} \gamma$ is removed from the $\mathrm{PN}$ dendrite into somatic vacuoles (Skinner et al., 2001). PKC $\gamma$ normally inactivates TRPC3 (Kwan et al., 2006) so its removal could allow slow mGluR1 currents to persist, particularly in the dendrites. Interestingly, mutations to PKC $\gamma$ in SCA14 also enhance TRPC 3 currents and disrupt cerebellar synaptic plasticity (Shuvaev et al., 2011).

We also observed prolonged mGluR1-dependent slow dendritic $\mathrm{Ca}^{2+}$ responses in SCA1 PN dendrites (Fig. 2E,F) that may arise from increased $\mathrm{Ca}^{2+}$ entry during the longer mGluR1mediated current. However, these currents normally make a minor contribution to mGluR1-dependent dendritic $\mathrm{Ca}^{2+}$ signals (Knöpfel et al., 2000; Canepari and Ogden, 2006) so other mechanisms must also contribute. Possibilities include increased mGluR1-dependent release of $\mathrm{Ca}^{2+}$ from $\mathrm{InsP}_{3}$ stores, as in SCA2 (Kasumu et al., 2012), slower uptake of $\mathrm{Ca}^{2+}$ (Fig. 2H) caused by reduced SERCA expression in this SCA1 model (Serra et al., 2004) or increased mGluR1-mediated inactivation of Kv4type $\mathrm{K}^{+}$channels leading to hyperexcitable $82 \mathrm{Q}$ PN outer den- drites (Otsu et al., 2014). But, like others (Inoue et al., 2001), we detected healthy depolarization-induced $\mathrm{PN} \mathrm{Ca}^{2+}$ responses and fast synaptic $\mathrm{Ca}^{2+}$ responses indicating remarkably effective adaptive remodeling of $\mathrm{Ca}^{2+}$ handling in $82 \mathrm{Q} P$ dendrites.

Together our results support enhanced mGluR1 signaling at PFs in moderate SCA1. We predict that with early loss of PN-specific EAAT4 (Serra et al., 2004), later loss of EAAT1 (Cvetanovic, 2015), altered $\mathrm{K}^{+}$currents (Hourez et al., 2011; Dell'Orco et al., 2015) and slowed $\mathrm{Ca}^{2+}$ uptake (Serra et al., 2004) the enhanced mGluR1 signaling in more compact PN dendrites ultimately promotes $\mathrm{PN} \mathrm{Ca}^{2+}$ overload, excitotoxicity, death, and end-stage ataxia.

mGluR1 NAM treatment restores motor function in SCA1

Nevertheless, earlier in the SCAlmodel the prolonged mGluR1 signaling provides an exciting therapeutic opportunity. Significantly, $82 Q$ mice treated with a very low dose of the mGluR1 NAM, JNJ16259685 improved their motor performance (Fig. $3 A, B$ ). A similarly low concentration of JNJ16259685 in vitro (5 nM) also reduced the prolonged $82 Q$ mGluR1 currents to $W T$ levels (Fig. $3 C-E$ ), thus providing a compelling link between prolonged PF-PN mGluR1 synaptic signaling and moderate SCA1 ataxia. It seems surprising that 
acute JNJ16259685 treatment improved motor performance in SCA1 mice given their permanently shrunken PNs (Fig. 1). However, in moderate SCA1, shrinkage is adaptive rather than degenerative and allows $82 \mathrm{Q} \mathrm{PNs}$ to sustain their firing (Dell'Orco et al., 2015) and may also allow them to respond to acute mGluR1 manipulation. JNJ could also influence other, unknown sites of elevated mGluR1 activity in $82 Q$ mice, but $82 \mathrm{Q}$ overexpression is restricted to PNs in these SCA1 mice suggesting that $\mathrm{PN}$ dysfunction is at the core of their ataxia and the probable target for our pharmacological intervention.

Given its critical role in cerebellar function, the role of mGluR1 in ataxia is likely to be far-reaching. Although successful therapy in late-stage SCA1 ataxia recently used a PAM to positively boost remaining mGluR 1 s (Notartomaso et al., 2013), reducing mGluR1 expression in SCA28 mice lowered $\mathrm{Ca}^{2+}$ responses and relieved ataxia (Maltecca et al., 2015). Our findings here suggest that removing excessive mGluR1 function successfully restores acute motor function in moderate SCA1 and provides exciting new momentum for mGluR1based pharmacological approaches to treat ataxia.

\section{References}

Armbrust KR, Wang X, Hathorn TJ, Cramer SW, Chen G, Zu T, Kangas T, Zink AN, Öz G, Ebner TJ, Ranum LP (2014) Mutant beta-III spectrin causes mGluRlalpha mislocalization and functional deficits in a mouse model of spinocerebellar ataxia type 5. J Neurosci 34:9891-9904. CrossRef Medline

Barnes JA, Ebner BA, Duvick LA, Gao W, Chen G, Orr HT, Ebner TJ (2011) Abnormalities in the climbing fiber-Purkinje cell circuitry contribute to neuronal dysfunction in ATXN1 [82Q] mice. J Neurosci 31:12778-12789. CrossRef Medline

Batchelor AM, Garthwaite J (1997) Frequency detection and temporally dispersed synaptic signal association through a metabotropic glutamate receptor pathway. Nature 385:74-77. CrossRef Medline

Becker EB, Oliver PL, Glitsch MD, Banks GT, Achilli F, Hardy A, Nolan PM, Fisher EM, Davies KE (2009) A point mutation in TRPC3 causes abnormal Purkinje cell development and cerebellar ataxia in moonwalker mice. Proc Natl Acad Sci U S A 106:6706-6711. CrossRef Medline

Canepari M, Ogden D (2006) Kinetic, pharmacological and activitydependent separation of two Ca2 + signalling pathways mediated by type 1 metabotropic glutamate receptors in rat Purkinje neurones. J Physiol 573:65-82. CrossRef Medline

Clark HB, Burright EN, Yunis WS, Larson S, Wilcox C, Hartman B, Matilla A, Zoghbi HY, Orr HT (1997) Purkinje cell expression of a mutant allele of SCA1 in transgenic mice leads to disparate effects on motor behaviors, followed by a progressive cerebellar dysfunction and histological alterations. J Neurosci 17:7385-7395. Medline

Cvetanovic M (2015) Decreased expression of glutamate transporter GLAST in bergmann glia is associated with the loss of Purkinje neurons in the spinocerebellar ataxia type 1. Cerebellum 14:8-11. CrossRef Medline

Dell'Orco JM, Wasserman AH, Chopra R, Ingram MA, Hu YS, Singh V, Wulff H, Opal P, Orr HT, Shakkottai VG (2015) Neuronal atrophy early in degenerative ataxia is a compensatory mechanism to regulate membrane excitability. J Neurosci 35:11292-11307. CrossRef Medline

Ferreira TA, Blackman AV, Oyrer J, Jayabal S, Chung AJ, Watt AJ, Sjostrom PJ, van Meyel DJ (2014) Neuronal morphometry directly from bitmap images. Nat Meth 11:982-984. http://www.nature.com/nmeth/journal/ v11/n10/full/nmeth.3125.html

Fogel BL, Hanson SM, Becker EB (2015) Do mutations in the murine ataxia gene TRPC3 cause cerebellar ataxia in humans? Mov Disord 30:284-286. CrossRef Medline

Fukunaga I, Yeo CH, Batchelor AM (2007) Potent and specific action of the mGlu1 antagonists YM-298198 and JNJ16259685 on synaptic transmission in rat cerebellar slices. Br J Pharmacol 151:870-876. CrossRef Medline

Guergueltcheva V, Azmanov DN, Angelicheva D, Smith KR, Chamova T, Florez L, Bynevelt M, Nguyen T, Cherninkova S, Bojinova V, Kaprelyan A, Angelova L, Morar B, Chandler D, Kaneva R, Bahlo M, Tournev I,
Kalaydjieva L (2012) Autosomal-recessive congenital cerebellar ataxia is caused by mutations in metabotropic glutamate receptor 1. Am J Hum Genet 91:553-564. CrossRef Medline

Hartmann J, Dragicevic E, Adelsberger H, Henning HA, Sumser M, Abramowitz J, Blum R, Dietrich A, Freichel M, Flockerzi V, Birnbaumer L, Konnerth A (2008) TRPC3 channels are required for synaptic transmission and motor coordination. Neuron 59:392-398. CrossRef Medline

Hourez R, Servais L, Orduz D, Gall D, Millard I, de Kerchove d'Exaerde A, Cheron G, Orr HT, Pandolfo M, Schiffmann SN (2011) Aminopyridines correct early dysfunction and delay neurodegeneration in a mouse model of spinocerebellar ataxia type 1. J Neurosci 31:11795-11807. CrossRef Medline

Ikeda Y, Dick KA, Weatherspoon MR, Gincel D, Armbrust KR, Dalton JC, Stevanin G, Dürr A, Zühlke C, Bürk K, Clark HB, Brice A, Rothstein JD, Schut LJ, Day JW, Ranum LP (2006) Spectrin mutations cause spinocerebellar ataxia type 5. Nat Genet 38:184-190. CrossRef Medline

Inoue T, Lin X, Kohlmeier KA, Orr HT, Zoghbi HY, Ross WN (2001) Calcium dynamics and electrophysiological properties of cerebellar Purkinje cells in SCA1 transgenic mice. J Neurophysiol 85:1750-1760. Medline

Kasumu AW, Liang X, Egorova P, Vorontsova D, Bezprozvanny I (2012) Chronic suppression of inositol 1,4,5-triphosphate receptor-mediated calcium signaling in cerebellar purkinje cells alleviates pathological phenotype in spinocerebellar ataxia 2 mice. J Neurosci 32:12786-12796. CrossRef Medline

Kato AS, Knierman MD, Siuda ER, Isaac JT, Nisenbaum ES, Bredt DS (2012) Glutamate receptor $\delta 2$ associates with metabotropic glutamate receptor 1 (mGluR1), protein kinase $\mathrm{C} \gamma$, and canonical transient receptor potential 3 and regulates mGluR1-mediated synaptic transmission in cerebellar Purkinje neurons. J Neurosci 32:15296-15308. CrossRef Medline

Knöpfel T, Anchisi D, Alojado ME, Tempia F, Strata P (2000) Elevation of intradendritic sodium concentration mediated by synaptic activation of metabotropic glutamate receptors in cerebellar Purkinje cells. Eur J Neurosci 12:2199-2204. CrossRef Medline

Konno A, Shuvaev AN, Miyake N, Miyake K, Iizuka A, Matsuura S, Huda F, Nakamura K, Yanagi S, Shimada T, Hirai H (2014) Mutant ataxin-3 with an abnormally expanded polyglutamine chain disrupts dendritic development and metabotropic glutamate receptor signaling in mouse cerebellar Purkinje cells. Cerebellum 13:29-41. CrossRef Medline

Kwan HY, Huang Y, Yao X (2006) Protein kinase C can inhibit TRPC3 channels indirectly via stimulating protein kinase G. J Cell Physiol 207: 315-321. CrossRef Medline

Lavreysen H, Wouters R, Bischoff F, Nóbrega Pereira S, Langlois X, Blokland S, Somers M, Dillen L, Lesage AS (2004) JNJ16259685, a highly potent, selective and systemically active mGlu1 receptor antagonist. Neuropharmacology 47:961-972. CrossRef Medline

Maltecca F, Baseggio E, Consolato F, Mazza D, Podini P, Young SM Jr, Drago I, Bahr BA, Puliti A, Codazzi F, Quattrini A, Casari G (2015) Purkinje neuron $\mathrm{Ca} 2+$ influx reduction rescues ataxia in SCA2 8 model. J Clin Invest 125:263-274. CrossRef Medline

Notartomaso S, Zappulla C, Biagioni F, Cannella M, Bucci D, Mascio G, Scarselli P, Fazio F, Weisz F, Lionetto L, Simmaco M, Gradini R, Battaglia G, Signore M, Puliti A, Nicoletti F (2013) Pharmacological enhancement of mGlul metabotropic glutamate receptors causes a prolonged symptomatic benefit in a mouse model of spinocerebellar ataxia type 1. Mol Brain 6:48. CrossRef Medline

Ohtani Y, Miyata M, Hashimoto K, Tabata T, Kishimoto Y, Fukaya M, Kase D, Kassai H, Nakao K, Hirata T, Watanabe M, Kano M, Aiba A (2014) The synaptic targeting of mGluR1 by its carboxyl-terminal domain is crucial for cerebellar function. J Neurosci 34:2702-2712. CrossRef Medline

Otsu Y, Marcaggi P, Feltz A, Isope P, Kollo M, Nusser Z, Mathieu B, Kano M, Tsujita M, Sakimura K, Dieudonné S (2014) Activity-dependent gating of calcium spikes by A-type $\mathrm{K}+$ channels controls climbing fiber signaling in Purkinje cell dendrites. Neuron 84:137-151. CrossRef Medline

Perkins EM, Clarkson YL, Sabatier N, Longhurst DM, Millward CP, Jack J, Toraiwa J, Watanabe M, Rothstein JD, Lyndon AR, Wyllie DJ, Dutia MB, Jackson M (2010) Loss of beta-III spectrin leads to Purkinje cell dys- 
function recapitulating the behavior and neuropathology of spinocerebellar ataxia type 5 in humans. J Neurosci 30:4857-4867. CrossRef Medline

Serra HG, Byam CE, Lande JD, Tousey SK, Zoghbi HY, Orr HT (2004) Gene profiling links SCA1 pathophysiology to glutamate signaling in Purkinje cells of transgenic mice. Hum Mol Genet 13:2535-2543. CrossRef Medline

Serra HG, Duvick L, Zu T, Carlson K, Stevens S, Jorgensen N, Lysholm A, Burright E, Zoghbi HY, Clark HB, Andresen JM, Orr HT (2006) RORalpha-mediated Purkinje cell development determines disease severity in adult SCA1 mice. Cell 127:697-708. CrossRef Medline

Shuvaev AN, Horiuchi H, Seki T, Goenawan H, Irie T, Iizuka A, Sakai N, Hirai H (2011) Mutant PKC $\gamma$ in spinocerebellar ataxia type 14 disrupts synapse elimination and long-term depression in Purkinje cells in vivo. J Neurosci 31:14324-14334. CrossRef Medline

Sillevis Smitt P, Kinoshita A, De Leeuw B, Moll W, Coesmans M, Jaarsma D, HenzenLogmans S, Vecht C, De Zeeuw C, Sekiyama N, Nakanishi S, Shigemoto R
(2000) Paraneoplastic cerebellar ataxia due to autoantibodies against a glutamate receptor. N Engl J Med 342:21-27. CrossRef Medline

Skinner PJ, Vierra-Green CA, Clark HB, Zoghbi HY, Orr HT (2001) Altered trafficking of membrane proteins in purkinje cells of SCA1 transgenic mice. Am J Pathol 159:905-913. CrossRef Medline

Wu H, Wang C, Gregory KJ, Han GW, Cho HP, Xia Y, Niswender CM, Katritch V, Meiler J, Cherezov V, Conn PJ, Stevens RC (2014) Structure of a class C GPCR metabotropic glutamate receptor 1 bound to an allosteric modulator. Science 344:58-64. CrossRef Medline

Zhou H, Lin Z, Voges K, Ju C, Gao Z, Bosman LW, Ruigrok TJ, Hoebeek FE, De Zeeuw CI, Schonewille M (2014) Cerebellar modules operate at different frequencies. Elife 3:e02536. CrossRef Medline

Zu T, Duvick LA, Kaytor MD, Berlinger MS, Zoghbi HY, Clark HB, Orr HT (2004) Recovery from polyglutamine-induced neurodegeneration in conditional SCA1 transgenic mice. J Neurosci 24:8853-8861. CrossRef Medline 